Original research article

\title{
Screening of the chemoprotective effect of 13 compounds and their mixtures with sodium 2-mercaptoethanesulfonate against 2-chloroethyl ethyl sulfide
}

\author{
Petr Jost, Jaroslav Pejchal *, Tomas Kucera, Lubica Muckova, Rudolf Stetina \\ University of Defense, Faculty of Military Health Sciences, Department of Toxicology and Military Pharmacy, Hradec Králové, Czech Republic
}

\begin{abstract}
2-chloroethyl ethyl sulfide (CEES) is a vesicant agent, commonly referred to half mustard due to its ability to form monofunctional adducts with DNA. In this study, we evaluated the chemoprotective potential of 13 compounds and their mixtures with sodium 2-mercaptoethanesulfonate (MESNA) against CEES-induced geno- and cytotoxicity in human lung cell line A-549. MESNA, L-glutathione (GSH), thiourea, sodium thiosulfate, hexamethylenetetramine, 4-acetamidophenol, asoxime dichloride (HI-6), N-acetyl-L-cysteine (NAC), sodium pyruvate, myo-inositol, 3-aminobenzamide (3-AB), nicotinamide, and $N_{\omega}$-nitro-L-arginine methyl ester hydrochloride and combinations of these compounds with MESNA were applied 30 min before CEES. DNA alkylation was measured using modified comet assay 1 and $24 \mathrm{~h}$ after the exposure. Cell viability was determined using MTT assay at 24 and $72 \mathrm{~h}$. The mono-therapeutical approach identified MESNA and GSH to provide significant chemoprotection. NAC and 3-AB supported DNA damage repair, while cell viability remained unaffected. Mixtures of GSH or NAC with MESNA showed protective synergism against DNA damage. Other compounds or their combinations with MESNA failed due to the potentiation of CEES-induced cytotoxicity. The chemoprotection against CEES remains limited; however, the combination of substances can provide protective synergy and may represent a promising strategy in the treatment of accidental exposure to monoalkylating agents.
\end{abstract}

Keywords: 2-chloroethyl ethyl sulfide; A-549 cell line; chemoprotection; comet assay; MESNA; MTT assay

Highlights:

- The chemoprotective effects of 13 compounds and 12 mixtures were screened against 2-chloroethyl ethyl sulfide.

- The most effective cytoprotection was provided by sodium 2-mercaptoethanesulfonate and L-glutathione solely.

- The combination of sodium 2-mercaptoethanesulfonate with $\mathrm{N}$-acetyl-L-cysteine or L-glutathione potentiates genoprotective effect.

\begin{abstract}
Abbreviations:
3-AB, 3-aminobenzamide; 4-AAP, 4-acetamidophenol; AlkA, 3-methyladenine DNA glycosylase II; CEES, 2-chloroethyl ethyl sulfide; DMEM, Dulbecco's modified Eagle's medium; DMSO, dimethyl sulfoxide; EDTA, ethylenediaminetetraacetic acid;

FBS, foetal bovine serum; GSH, L-glutathione; HI-6, asoxime dichloride; HMT, hexamethylenetetramine; HPLC-MS, high performance liquid chromatography-mass spectrometry; L-NAME, $N_{\omega}$-nitro-L-arginine methyl ester hydrochloride; MESNA, sodium 2-mercaptoethanesulfonate; MI, myo-inositol; MTT, 3-(4,5-dimethylthiazol-2-yl)-2,5-diphenyltetrazolium bromide; NAC, $N$-acetylL-cysteine; $\mathrm{NaCl}$, sodium chloride; $\mathrm{NAD}^{+}$, nicotinamide adenine dinucleotide (oxidized form); $\mathrm{NAm}$, nicotinamide; $\mathrm{NaOH}$, sodium hydroxide; PARP, poly-(ADP-ribose) polymerase; PBS, phosphate-buffered saline; PYR, sodium pyruvate; STS, sodium thiosulfate; Tris, tris(hydroxymethyl)aminomethane; TU, thiourea.
\end{abstract}

\section{Introduction}

2-chloroethyl ethyl sulfide (CEES) is a vesicant agent frequently used in research to simulate sulfur mustard (SM) poisoning. Unlike SM, the substance is less toxic but commercially available. CEES induces DNA damage in the form of monofunctional adducts, which is in contrast to SM, a bifunctional alkylating agent capable of forming DNA-DNA crosslinks (Abel et al., 2011; Gould et al., 2009; Kehe et al., 2013). This difference significantly limits their interchangeability and toxic properties (Sawyer et al., 2017). Table 1 summarizes physico-chemical properties of both substances. In this context, CEES remains an important accessible model molecule for both understanding the DNA alkylation mechanisms and SM-countermeasure research (Inturi et al., 2011; Tewari-Singh et al., 2014).

\footnotetext{
* Author for correspondence: Jaroslav Pejchal, University of Defence, Faculty of Military Health Sciences, Department of Toxicology and Military Pharmacy, Trebesska 1575, 50001 Hradec Kralove, Czech Republic; e-mail:jaroslav.pejchal@unob.cz http://doi.org/10.32725/jab.2019.009
}

Submitted: 2017-12-06 • Accepted: 2019-06-03 • Prepublished online: 2019-06-17

J Appl Biomed 17/2: 136-145 • EISSN 1214-0287 • ISSN 1214-021X

(c) 2019 The Authors. Published by University of South Bohemia in České Budějovice, Faculty of Health and Social Sciences.

This is an open access article under the CC BY-NC-ND license. 
Table 1. Comparison of physico-chemical properties of the sulfur mustard and 2-chloroethyl ethyl sulfide

\begin{tabular}{|c|c|c|}
\hline Property name & Sulfur mustard & $\begin{array}{l}\text { 2-Chloroethyl ethyl } \\
\text { sulfide }\end{array}$ \\
\hline Signification & SM or HD & CEES \\
\hline CAS number & $505-60-2$ & $693-07-2$ \\
\hline Coulor & Colourless oily liquid & Colourless liquid \\
\hline Odour & Mustard, garlic & Mild sulfide \\
\hline Formula & $\mathrm{C}_{4} \mathrm{H}_{8} \mathrm{Cl}_{2} \mathrm{~S}$ & $\mathrm{C}_{4} \mathrm{H}_{9} \mathrm{ClS}$ \\
\hline $\begin{array}{l}\text { Molecular } \\
\text { weight }\end{array}$ & $159.068 \mathrm{~g} \cdot \mathrm{mol}^{-1}$ & $124.626 \mathrm{~g} \cdot \mathrm{mol}^{-1}$ \\
\hline Density at $20^{\circ} \mathrm{C}$ & $1.274 \mathrm{~g} . \mathrm{cm}^{-3}$ & $1.066 \mathrm{~g} . \mathrm{cm}^{-3}$ \\
\hline Melting point & $13-14^{\circ} \mathrm{C}$ & Not available \\
\hline Boiling point & $216^{\circ} \mathrm{C}$ & $156^{\circ} \mathrm{C}$ \\
\hline Water solubility & Very poor, hydrolysis & Slightly, hydrolysis \\
\hline
\end{tabular}

Thirteen substances were chosen for testing their chemoprotective potential against CEES-induced cell injury. The substances were classified into 5 groups according to their structure and/or properties (Table 2). The first group includes sodium 2-mercaptoethanesulfonate (MESNA), L-glutathione (GSH), thiourea (TU), and sodium thiosulfate (STS), i.e. the compounds containing nucleophilic sulfur with the potential to scavenge CEES as well as reactive oxygen species, which has been associated with CEES toxicity (Inturi et al., 2011; Maher, 2017; Ravindran et al., 2017; Srivastava et al., 2011;
Yiannakopoulou et al., 2012). The second group comprises hexamethylenetetramine (HMT), 4-acetamidophenol (4-AAP) and asoxime dichloride (HI-6), all with nucleophilic nitrogen as a potential target atom. The third group is represented by antioxidants such as $N$-acetyl-L-cysteine (NAC), sodium pyruvate (PYR) and myo-inositol (MI) (Hara et al., 2017; Kładna et al., 2015; Palmieri et al., 2016). The fourth group consists of 3-aminobenzamide (3-AB) and nicotinamide (NAm). Both are poly-(ADP-ribose) polymerase (PARP) inhibitors (Guzyk et al., 2016). PARP is activated in the presence of CEES-induced damage and initiates repair process via $\mathrm{NAD}^{+}$dependent ADP-ribosylation, depleting cellular $\mathrm{NAD}^{+}$pool (Debiak et al., 2016). This mechanism has been postulated to be responsible for necrotic cell death after exposure to vesicant agents (Kehe et al., 2008). Finally, the fifth group contains $N_{\omega}$-nitro-L-arginine methyl ester hydrochloride (L-NAME), a nitric oxide synthase inhibitor. Generation of nitric oxide activates apoptosis and inflammatory signals after CEES challenge (Sagar et al., 2017).

Our aim was to evaluate the protective effect of abovementioned compounds against DNA damage using modified comet assay (Jost et al., 2015) 1 and $24 \mathrm{~h}$ after exposure to $500 \mu \mathrm{M}$ CEES and against CEES-induced cytotoxicity assessed by MTT assay at 24 and $72 \mathrm{~h}$. Additionally, mixtures with MESNA were tested to examine possible protective synergy. In vitro model of human lung adenocarcinoma cell line A-549 was utilized in order to mimic the injury of lung epithelial cells as a possible route of poisoning from blistering agents (Balali-Mood and Hefazi, 2006). Despite A-549 cell line has cancer origin and does not fully reflect primary lung cells, due to CEES's non-specific course of action, the model is sufficient to assess the chemoprotective effect of the tested substances in vitro.

Table 2. Summary of tested chemoprotective compounds and mixtures

\begin{tabular}{|c|c|c|c|}
\hline Group $^{\mathrm{a}}$ & Compound & Non-toxic conc. $(\mathrm{mM})^{\mathrm{b}}$ & Mixture composition MESNA + substance $(\mathrm{mM})^{c}$ \\
\hline \multirow{4}{*}{1} & Sodium 2-mercaptoethanesulfonate & 1 & - \\
\hline & L-Glutathione reduced & 2 & $1+2$ \\
\hline & Thiourea & 4 & $1+4$ \\
\hline & Sodium thiosulfate & 8 & $1+8$ \\
\hline \multirow{4}{*}{2} & Hexamethylenetetramine & 0.5 & $1+0.5$ \\
\hline & 4-Acetamidophenol & 0.5 & $1+0.5$ \\
\hline & Asoxime dichloride & 0.5 & $1+0.5$ \\
\hline & $\mathrm{N}$-acetyl-L-cysteine & 2 & $1+2$ \\
\hline \multirow{2}{*}{3} & Myo-inositol & 3 & $1+3$ \\
\hline & Sodium pyruvate & 4 & $1+4$ \\
\hline \multirow{2}{*}{4} & 3-Aminobenzamide & 0.5 & $1+0.5$ \\
\hline & Nicotinamide & 2 & $1+2$ \\
\hline 5 & $N_{\omega}$-nitro-L-arginine methyl ester hydrochloride & 4 & $1+4$ \\
\hline \multicolumn{4}{|c|}{$\begin{array}{l}\text { a Substances were divided into } 5 \text { groups according to their structure and/or properties: 1) compounds containing sulfur or SH-group; 2) substances } \\
\text { containing nitrogen; } 3 \text { ) antioxidants; } 4 \text { ) poly-(ADP-ribose) polymerase inhibitors; 5) nitric oxide synthase inhibitor. } \\
\text { b Maximal cell-tolerated concentrations of tested substances obtained from dose-response experiments on the A-549 cell treated for } 72 \mathrm{~h} \text {. } \\
\text { Cell viability was determined by MTT assay (see methods). } \\
\text { c Composition of MESNA-containing mixtures. The numbers represent final concentrations of each component. Mixture-treated A-549 cells (without } \\
\text { CEES) did not influence cell viability measured by MTT assay (Jost et al., 2017). }\end{array}$} \\
\hline
\end{tabular}




\section{Materials and methods}

\section{Cell and cell culture}

Human lung adenocarcinoma cell line A-549 (American type culture collection, Rockville, MD, USA) was grown in Dulbecco's modified Eagle's medium (DMEM) supplemented with $10 \%$ foetal bovine serum (FBS) and 1\% antibiotic/antimycotic solution (all from PAA Laboratories $\mathrm{GmbH}$, Pasching, Austria) in a controlled atmosphere with a temperature of $37^{\circ} \mathrm{C}$, $5 \% \mathrm{CO}_{2}$ concentration and $85-90 \%$ relative humidity. Cells were routinely passaged by trypsinization every 2-3 days.

\section{Chemicals and reagents}

2-chloroethyl ethyl sulfide (CEES, CAS\#: 693-07-2), sodium 2-mercaptoethanesulfonate (MESNA, CAS\#: 19767-45-4), L-glutathione (GSH, CAS\#: 70-18-8), thiourea (TU, CAS\#: 62-56-6), sodium thiosulfate (STS, CAS\#: 19767-45-4), hexamethylenetetramine (HMT, CAS\#: 100-97-0), 4-acetamidophenol (4-AAP, CAS\#: 103-90-2), $N$-acetyl-L-cysteine (NAC, CAS\#: 616-91-1), myo-inositol (MI, CAS\#: 87-89-8), sodium pyruvate (PYR, CAS\#: 113-24-6), 3-aminobenzamide (3-AB, CAS\#: 3544-24-9), nicotinamide (NAm, CAS\#: 98-92-0), and $N_{\omega}$-nitro-L-arginine methyl ester hydrochloride (L-NAME, CAS\#: 51298-62-5) were purchased from Sigma-Aldrich (Saint Louis, MO, USA).

Asoxime dichloride (HI-6, CAS\#: 34433-31-3, purity 98\%, HPLC-MS) was synthesized at the Department of Toxicology and Military Pharmacy (Faculty of Military Health Science, University of Defence, Hradec Kralove, Czech Republic).

\section{Experimental design}

A-549 cells were first treated with CEES at a concentration of $62.5,125,250$, and $500 \mu \mathrm{M}$ in order to determine the dose-response relationship to DNA damage and cell viability. The DNA damage was measured at 1 and $24 \mathrm{~h}$ and cell viability were assessed in the 24 and $72 \mathrm{~h}$ interval. The concentration of $500 \mu \mathrm{M}$ was selected as optimal for further testing by both assays.

A-549 cells were pretreated with tested compounds (dissolved in culture medium) or their mixtures with MESNA at final concentrations (see Table 1) for $30 \mathrm{~min}$. These concentrations represent the highest concentrations, which do not reduce the viability of A-549 cells measured by MTT assay during $72 \mathrm{~h}$ interval (Jost et al., 2017). The control cells were incubated with culture medium only. Subsequently, CEES was added to the final concentration of $500 \mu \mathrm{M}$. The cells were further incubated until DNA damage was measured at 1 and $24 \mathrm{~h}$. Cell viability assessment was done in the 24 and $72 \mathrm{~h}$ interval after CEES treatment.

\section{DNA alkylation damage detection}

CEES-induced DNA damage was quantified by a modified alkaline single cell gel electrophoresis (comet assay). This method is suitable for the measurement of single-strand DNA breaks. However, CEES-DNA adducts are relatively alkali-stable and cannot be analyzed directly. By incorporating an extra step, in which the DNA is digested by lesion-specific enzyme 3-methyladenine DNA glycosylase II (AlkA), additional breaks are formed. The presence of a specific substrate for the AlkA increases the amount of DNA breaks in comparison with the base level (Collins et al., 2001).

Cells $\left(2 \times 10^{5}\right)$ were plated into a $40 \mathrm{~mm}$ diameter Petri dish and left to attach overnight. The alkaline comet assay was performed according to (Collins et al., 2001) with few modifications. After the treatment, the medium was aspirated. Cells were washed with ice-cold phosphate-buffered saline (PBS) and trypsinized (0.25\% trypsin with $0.02 \%$ EDTA $4 \mathrm{Na}$; Sigma-Aldrich). $35 \mu$ of cell suspension in PBS (Sigma-Aldrich) was mixed with $1 \%$ low melting point agarose (Serva Electrophoresis $\mathrm{GmbH}$, Heidelberg, Germany) at $37{ }^{\circ} \mathrm{C}$ to a final concentration of $24 \times 10^{4}$ cells $/ \mathrm{ml}$ and $85 \mu$ l of this suspension was pipetted onto slides pre-coated with high-melting-point agarose (Serva Electrophoresis $\mathrm{GmbH}$ ). Slides were allowed to solidify at $4{ }^{\circ} \mathrm{C}$ on the cooling plate.

The slides with gels were placed into a freshly prepared lysis buffer ( $\mathrm{pH} 10,4^{\circ} \mathrm{C}$; $100 \mathrm{mM}$ EDTA, $2.5 \mathrm{M} \mathrm{NaCl}, 10 \mathrm{mM}$ Tris [all from Penta, Prague, Czech Republic], and 1\% Triton X-100; Serva Electrophoresis $\mathrm{GmbH}$ ) for 1 hour. After the lysis, the slides were rinsed in AlkA buffer ( $\mathrm{pH} 8.0 ; 40$ mM Hepes, $0.2 \mathrm{mg} / \mathrm{ml}$ bovine serum albumin [both from Sigma-Aldrich] and $0.5 \mathrm{mM}$ EDTA prepared according to Collins et al., 2001) three times for $5 \mathrm{~min}$. The enzyme 3-methyladenine DNA glycosylase II (EC 3.2.2.21; AlkA; kindly provided by Dr. Angelis, Institute of Experimental Botany, Academy of Sciences of the Czech Republic, Prague, Czech Republic) at an original concentration of $0.4 \mathrm{mg} / \mathrm{ml}$ was diluted $1000 \times$ and dosed at $35 \mu \mathrm{l}$ directly onto the gel, which was then covered with a coverslip. Cell slides were incubated in a humidity chamber at $37{ }^{\circ} \mathrm{C}$ for $45 \mathrm{~min}$. After the incubation, coverslips were removed and slides were transferred into a horizontal electrophoresis chamber and incubated in electrophoresis buffer $(\mathrm{pH} \geq 13 ; 300 \mathrm{mM}$ $\mathrm{NaOH}, 1 \mathrm{mM}$ EDTA; both from Penta) at $4{ }^{\circ} \mathrm{C}$ for $40 \mathrm{~min}$ for alkali DNA unwinding.

Electrophoresis was performed in the same buffer at $25 \mathrm{~V}$ and $300 \mathrm{~mA}(0.75 \mathrm{~V} / \mathrm{cm})$ at $4{ }^{\circ} \mathrm{C}$ for $30 \mathrm{~min}$. After the process, the slides were rinsed with neutralization buffer $(\mathrm{pH} 7.5$; 0.4 M Tris; Penta) three times for 5 min and washed with distilled water. The slides were then air-dried at room temperature and stored in the dark until the image analysis (maximally two weeks).

Before image analysis, the slides were rehydrated in deionized water and stained with $20 \mu \mathrm{l}$ of ethidium bromide $(20 \mu \mathrm{g} /$ ml; Sigma-Aldrich). Nikon epifluorescence microscope with a mercury light source and LUCIA ${ }^{\circledR}$ comet assay software (Laboratory Imaging, Ltd., Prague, Czech Republic) were used for the analysis. The evaluation was blinded by independent coding. Fifty cells were randomly selected per slide and \%tail DNA, which increases proportionally with the presence of alkyl-DNA adducts, was measured by the image analysis software. The resulting value of \%tail DNA was calculated as the mean \pm standard deviation from three independent measurements.

\section{Cell viability assay}

Cell viability was measured by reduction of 3-(4,5-dimethylthiazol-2-yl)-2,5-diphenyltetrazolium bromide (MTT, Sigma-Aldrich). Living cells are able to reduce yellow MTT tetrazolium salt to purple crystals of formazan (Mosmann, 1983). Cells were seeded in a 96-well plate ( 4 or $8 \times 10^{3}$ cells per well for 72 and $24 \mathrm{~h}$ interval, respectively) and incubated at $37{ }^{\circ} \mathrm{C}$ in a $5 \% \mathrm{CO}_{2}$ incubator (Binder, Tuttlingen, Germany) overnight. After the treatment with serially diluted CEES or with protective compounds and CEES, the medium was aspirated and replaced by fresh medium containing 1/10 MTT stock solution (5 mg/ml) in each well. The plate was incubated at $37{ }^{\circ} \mathrm{C}$ in a $\mathrm{CO}_{2}$ incubator for $90 \mathrm{~min}$. Subsequently, the medium was aspirated and formazan crystals dissolved in $100 \mu \mathrm{l}$ dimethyl sulfoxide (DMSO; Sigma-Aldrich). The plate was shaken and the optical density of each well was measured on a Synergy 
2 Multi-Mode Microplate Reader (BioTek Instruments, Inc., VT, USA) at $570 \mathrm{~nm}$. Cell viability was expressed as a percentage of the untreated control. Each measurement was performed in triplicate in three independent experiments.

\section{Data analysis}

Statistical analysis was performed in GraphPad Prism version 5.04 for Windows (GraphPad Software, San Diego, CA, USA) using one-way analysis of variance (ANOVA) and Dunnett's Multiple Comparison Test to evaluate significant differences. The level of significance was set at $\alpha=0.05$. Experimental data are shown as mean \pm standard deviation calculated from three independent experiments.

The data for CEES (positive control) represents the mean value from all experiments (black columns in Figs 2-6). Results from single experiments were very similar and differed less than $\pm 10 \%$. Before pooling the data, we analysed the results by nonparametric Kruskal-Wallis test, showing no differences among groups.

\section{Results}

The effect of CEES on DNA damage and cell viability is in Fig. 1. \%tail DNA significantly increased by $28.5 \%, 44.7 \%, 77.6 \%$, and $98.0 \%$ at $1 \mathrm{~h}$ and by $6.5 \%, 31.5 \%, 66.6 \%$, and $89.6 \% 24 \mathrm{~h}$ after CEES treatment at concentrations of $62.5,125,250$, and $500 \mu \mathrm{M}$, respectively. Cell viability was significantly decreased by $98.1 \%, 85.1 \%$ and $83.0 \%$ in the $24 \mathrm{~h}$ interval and by $83.1 \%$, $79.5 \%$ and $74.4 \% 72 \mathrm{~h}$ after CEES treatment at concentrations of 125,250 and $500 \mu \mathrm{M}$, respectively.
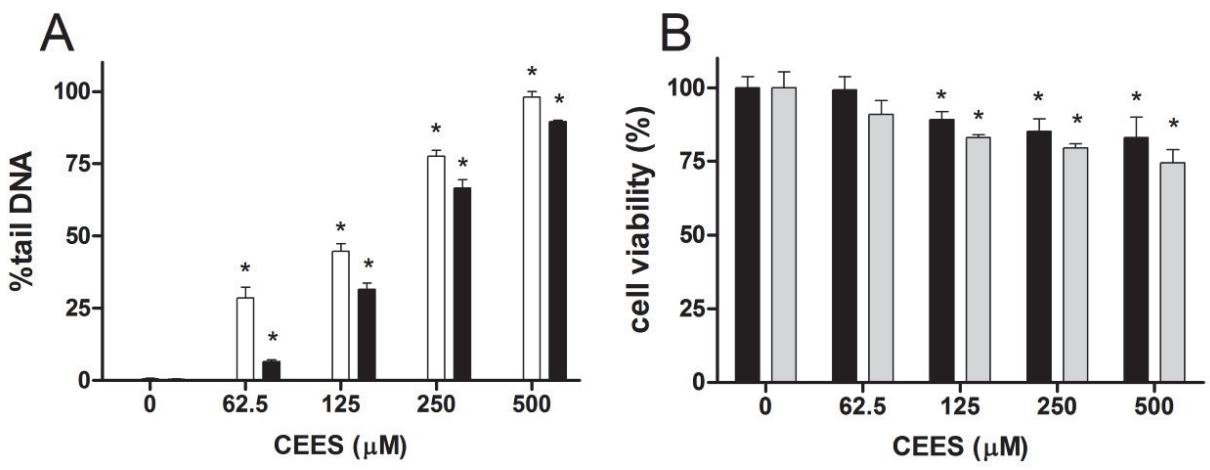

Fig. 1. DNA damage and viability of A-549 cells treated with CEES at concentrations of 62.5, 125, 250, and 500 $\mu \mathrm{M}$.

(A) Exposed cells were incubated for 1 (white columns) and $24 \mathrm{~h}$ (black columns) and the amount of damaged DNA was assessed by comet assay modified to detect DNA alkylation.

(B) Cell viability was measured at 24 (black columns) and $72 \mathrm{~h}$ (grey columns) by MTT assay.

Significantly different values compared with DMSO treated group (negative control): * $p \leq 0.05$.

Results of the first group of tested substances containing sulfur or SH-group as a target for CEES are shown in Fig. 2.

MESNA significantly reduced \%tail DNA by $31 \%$ and increased cell viability by $8 \% 24 \mathrm{~h}$ after CEES administration.

GSH decreased \%tail DNA by $21 \%$ in the $24 \mathrm{~h}$ interval. It was the only compound increasing cell viability in both time intervals (by $4 \%$ and $10 \%$ at 24 and $72 \mathrm{~h}$, respectively). In combination with MESNA, \%tail DNA decreased by $6 \%$ in the $1 \mathrm{~h}$ interval and by $48 \%$ in the $24 \mathrm{~h}$ interval. Cell viability was not affected by the mixture.

TU significantly reduced \%tail DNA by $12 \% 24 \mathrm{~h}$ after CEES treatment. On the other hand, cell viability was $7 \%$ and $33 \%$ lower than in positive control in the 24 and $72 \mathrm{~h}$ interval, respectively. When mixed with MESNA, it caused $8 \%$ reduction of \%tail DNA $24 \mathrm{~h}$ after CEES administration. Cell viability decreased by $42 \%$ and $91 \%$ at 24 and 72 h, respectively.

STS decreased \%tail DNA by $54 \% 24 \mathrm{~h}$ after CEES exposure and cell viability by $31 \%$ and $73 \%$ at 24 and 72 h, respectively. In combination with MESNA, \%tail DNA was reduced by $8 \%$ in the $1 \mathrm{~h}$ interval and by $57 \%$ in the $24 \mathrm{~h}$ interval. Cell viability decreased only at $72 \mathrm{~h}$ (by 20\%).

Results of the second group of tested compounds are in Fig. 3. HMT significantly reduced \%tail DNA by $79 \% 24 \mathrm{~h}$ after CEES treatment. However, this was accompanied by a decrease in cell viability in both time intervals (by $61 \%$ and $94 \%$ at 24 and $72 \mathrm{~h}$, respectively). Similar results were found when mixed with MESNA. DNA damage expressed by \%tail DNA decreased by $30 \%$ in the $24 \mathrm{~h}$ interval and cell viability was $11 \%$ and $56 \%$ lower than in positive control at 24 and $72 \mathrm{~h}$, respectively.

4-AAP did not affect \%tail DNA. Cell viability decreased only in the $72 \mathrm{~h}$ interval (by 7\%). Similarly, in combination with MESNA, no change in \%tail DNA was measured and cell viability was reduced by $8 \% 72 \mathrm{~h}$ after CEES treatment.

HI- 6 caused a $12 \%$ decrease in \%tail DNA in the $24 \mathrm{~h}$ interval. Cell viability decreased by $13 \%$ and $15 \%$ at 24 and $72 \mathrm{~h}$, respectively. In mixture with MESNA, \%tail DNA was reduced by $23 \% 24 \mathrm{~h}$ after CEES treatment and cell viability was $15 \%$ lower than in positive control in both time intervals.

Results of the third group of tested substances are depicted in Fig. 4. NAC caused 33\% decrease in \%tail DNA $24 \mathrm{~h}$ after CEES treatment. Cell viability was not affected by this compound. When administered with MESNA, \%tail DNA decreased by $18 \%$ and $46 \%$ at 1 and 24 h, respectively. No significant change in cell viability was measured.

MI caused 14\% decrease in \%tail DNA in the $24 \mathrm{~h}$ interval and $8 \%$ and $14 \%$ decrease in cell viability 24 and $72 \mathrm{~h}$ after CEES treatment, respectively. In combination with MESNA, reduction of \%tail DNA in the $24 \mathrm{~h}$ interval was more profound (by $36 \%$ ), whereas cell viability was not influenced.

PYR did not protect against DNA damage. Moreover, cell viability was $8 \%$ lower than in positive control at both time intervals. When used with MESNA, \%tail DNA decreased by $22 \%$ $24 \mathrm{~h}$ after CEES treatment, while cell viability was reduced by $8 \%$ at $72 \mathrm{~h}$. 

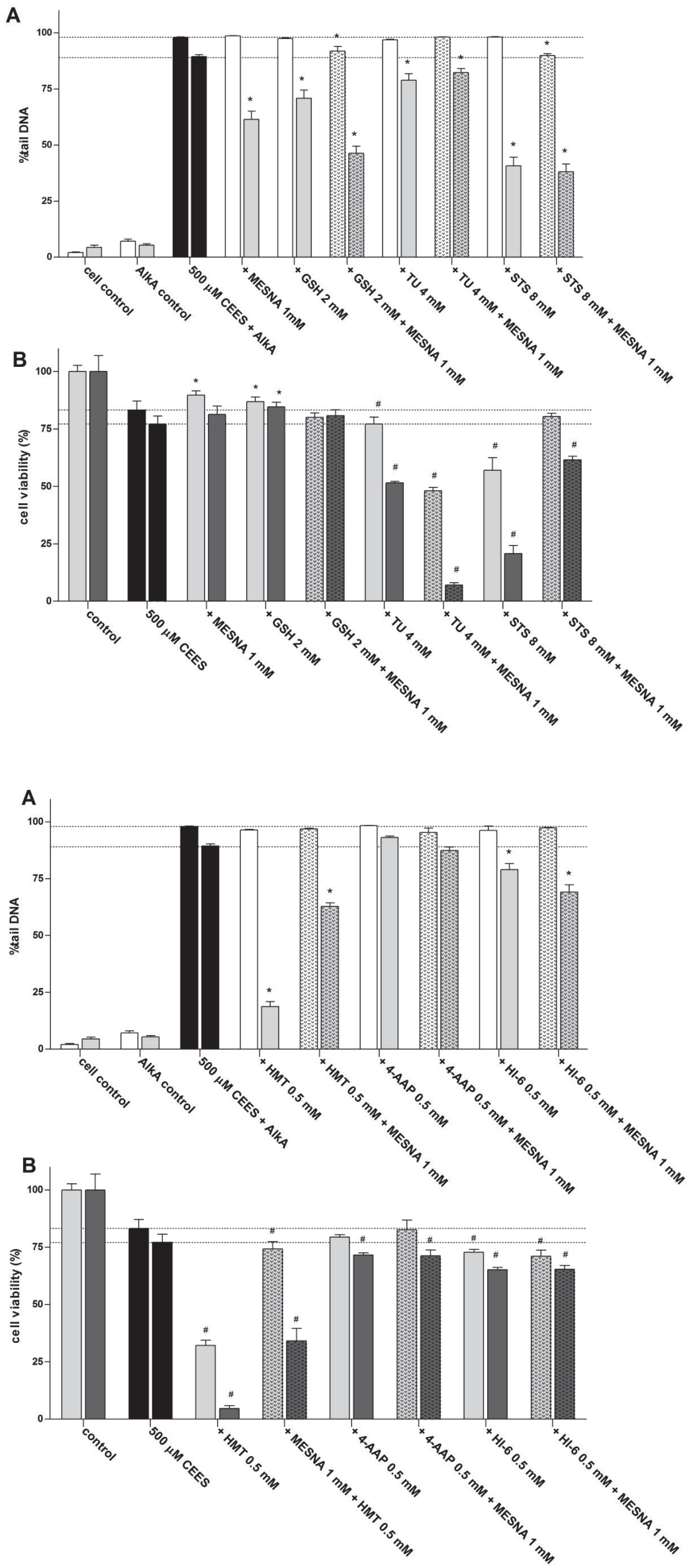

Fig. 2. Protective effect of substances containing sulfur or SH-group: sodium 2-mercaptoethanesulfonate (MESNA), L-glutathione (GSH), thiourea (TU), sodium thiosulfate (STS), and their mixtures with MESNA (patterned columns) against CEES-induced DNA damage and loss of cell viability. A-549 cells were pretreated with tested compounds or their mixtures for 30 min and CEES was added at a final concentration of $500 \mu \mathrm{M}$.

(A) Exposed cells were subsequently incubated for 1 (white columns) and $24 \mathrm{~h}$ (grey columns) and the amount of DNA adducts was assessed by comet assay modified to detect DNA alkylation damage.

(B) Cell viability was measured at 24 (grey columns) and $72 \mathrm{~h}$ (dark grey columns) by MTT assay.

Significantly different values compared with CEES solely exposed cells (black columns, positive control):

${ }^{*} p \leq 0.05$ (protective effect); \# $p \leq 0.05$ (potentiation of CEES-induced adverse effects).

Fig. 3. Protective effect of compounds containing nitrogen as a potential target atom: hexamethylenetetramine (HMT), 4-acetamidophenol (4-AAP), asoxime dichloride (HI-6) and their mixture with MESNA (patterned columns) against CEESinduced DNA damage and loss of cell viability. A-549 cells were pretreated with tested compounds or their mixtures for $30 \mathrm{~min}$ and CEES was added at a final concentration of $500 \mu \mathrm{M}$.

(A) Exposed cells were subsequently incubated for 1 (white columns) and $24 \mathrm{~h}$ (grey columns) and the amount of DNA adducts was assessed by comet assay modified to detect DNA alkylation damage.

(B) Cell viability was measured at 24 (grey columns) and $72 \mathrm{~h}$ (dark grey columns) by MTT assay.

Significantly different values compared with CEES solely exposed cells (black columns, positive control):

${ }^{*} p \leq 0.05$ (protective effect); $\# p \leq 0.05$ (potentiation of CEES-induced adverse effects). 

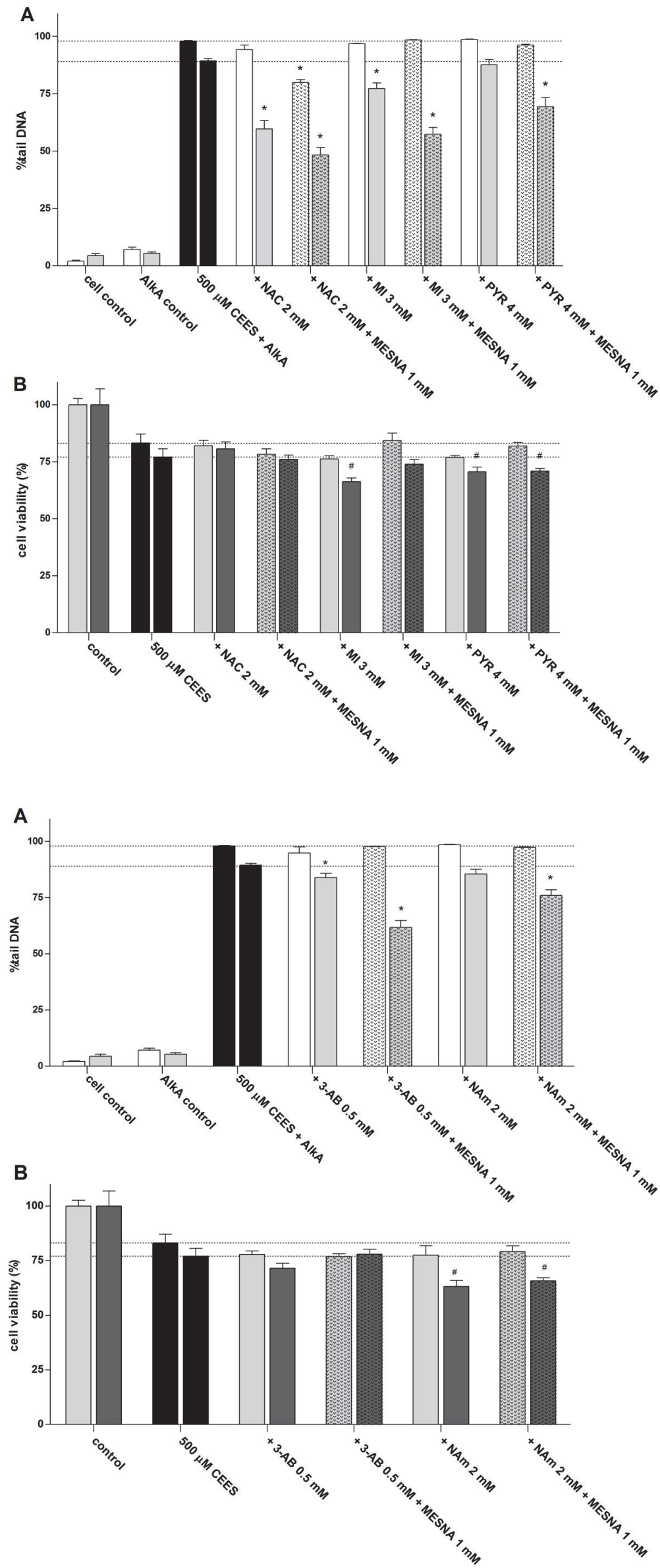

Fig. 4. Protective effect of antioxidants: $N$-acetyl-Lcysteine (NAC), sodium pyruvate (PYR), myo-inositol (MI) and their mixture with MESNA (patterned columns) against CEES-induced DNA damage and loss of cell viability. A-549 cells were pretreated with tested compounds or their mixtures for $30 \mathrm{~min}$ and CEES was added at a final concentration of $500 \mu \mathrm{M}$.

(A) Exposed cells were subsequently incubated for 1 (white columns) and $24 \mathrm{~h}$ (grey columns) and the amount of DNA adducts was assessed by comet assay modified to detect DNA alkylation.

(B) Cell viability was measured at 24 (grey columns) and $72 \mathrm{~h}$ (dark grey columns) by MTT assay.

Significantly different values compared with CEES solely exposed cells (black columns, positive control):

${ }^{*} p \leq 0.05$ (protective effect); $\# p \leq 0.05$ (potentiation of CEES-induced adverse effects).

Fig. 5. Protective effect of poly(ADP-ribose)polymerase inhibitors: 3-aminobenzamide (3-AB), nicotinamide (NAm) and their mixture with MESNA (patterned columns) against CEES-induced DNA damage and loss of cell viability. A-549 cells were pretreated with tested compounds or their mixtures for $30 \mathrm{~min}$ and CEES was added at a final concentration of $500 \mu \mathrm{M}$.

(A) Exposed cells were subsequently incubated for 1 (white columns) and $24 \mathrm{~h}$ (grey columns) and the amount of DNA adducts was assessed by comet assay modified to detect DNA alkylation damage.

(B) Cell viability was measured at 24 (grey columns) and $72 \mathrm{~h}$ (dark grey columns) by MTT assay.

Significantly different values compared with CEES solely exposed cells (black columns, positive control):

* $p \leq 0.05$ (protective effect); \# $p \leq 0.05$ (potentiation of CEES-induced adverse effects). 


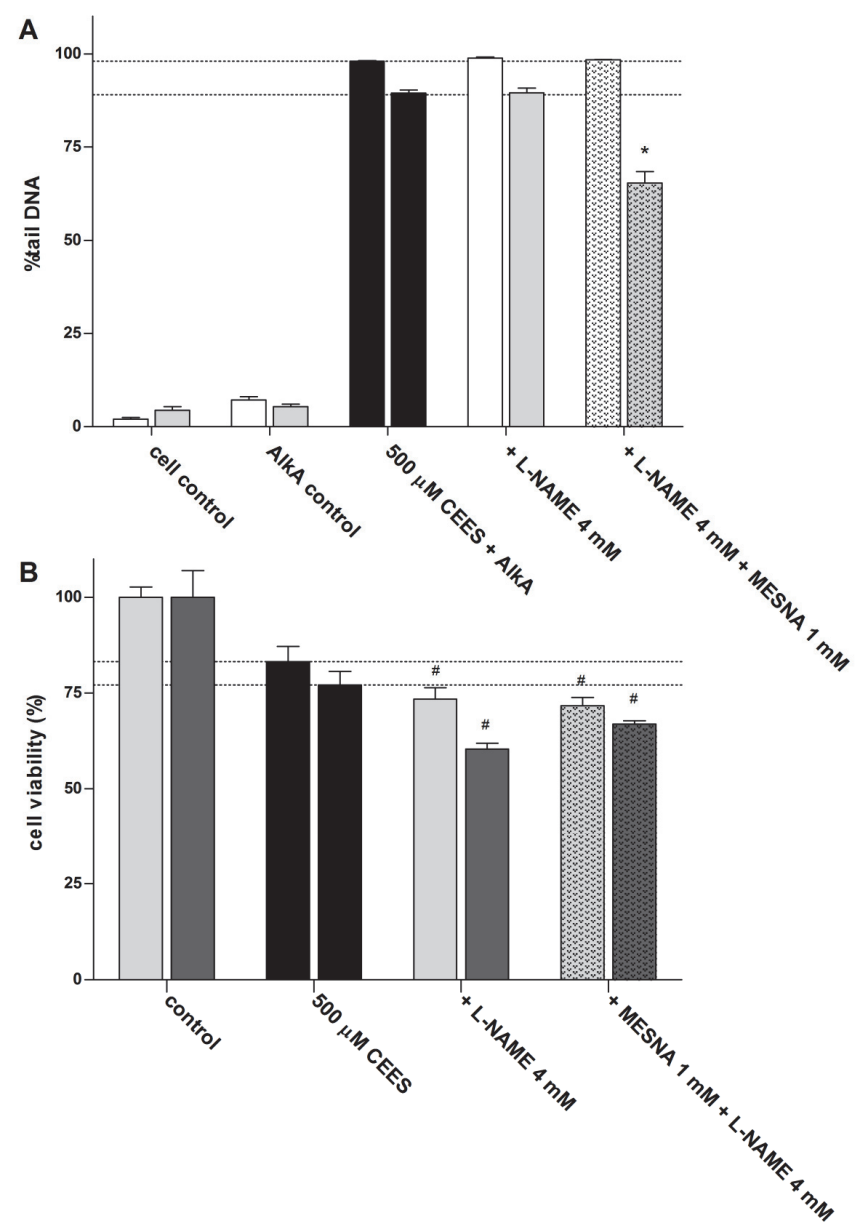

Fig. 6. Protective effect of nitric oxide synthase inhibitor $N_{\omega}$-nitro-Larginine methyl ester hydrochloride (L-NAME) and its mixture with MESNA (patterned columns) against CEES-induced DNA damage and loss of cell viability. A-549 cells were pretreated with tested compounds or their mixtures for $30 \mathrm{~min}$ and CEES was added at a final concentration of $500 \mu \mathrm{M}$.

(A) Exposed cells were subsequently incubated for 1 (white columns) and $24 \mathrm{~h}$ (grey columns) and the amount of DNA adducts was assessed by comet assay modified to detect DNA alkylation.

(B) Cell viability was measured at 24 (grey columns) and $72 \mathrm{~h}$ (dark grey columns) by MTT assay.

Significantly different values compared with CEES solely exposed cells (black columns, positive control):

${ }^{*} p \leq 0.05$ (protective effect); $\# p \leq 0.05$ (potentiation of CEES-induced adverse effects).

Results of the fourth group of tested substances are depicted in Fig. 5. 3-AB and its mixture with MESNA significantly reduced \%tail DNA by $6 \%$ and $31 \% 24 \mathrm{~h}$ after CEES treatment, respectively. Cell viability was unaffected in both groups.

The second inhibitor NAm did not protect against CEES-induced DNA damage and decreased cell viability by $18 \%$ in the $72 \mathrm{~h}$ interval. In combination with MESNA, $15 \%$ reduction in both \%tail DNA at $24 \mathrm{~h}$ and cell viability at $72 \mathrm{~h}$ was found.

Results of the fifth group containing a nitric oxide synthase inhibitor are shown in Fig. 6. L-NAME did not affect CEES-induced DNA damage and decreased cell viability in both time intervals (by $12 \%$ and $22 \%$ at 24 and 72 h, respectively). Its combination with MESNA reduced \%tail DNA by $27 \% 24$ after incubation with CEES; however, cell viability remained decreased in both time intervals (by $14 \%$ and $13 \%$ at 24 and 72 h, respectively).

\section{Discussion}

In the present study, we tested the chemoprotective effect of 13 compounds and 12 mixtures against CEES-induced damage. Based on the dose-response experiments, the final concentration of CEES was set to $500 \mu \mathrm{M}$. At this concentration, \%tail DNA reached nearly $100 \%$. Therefore, the utilization of higher concentrations might affect the results due to the saturation effect. The solubility of CEES is also another limiting factor. At a concentration of $1000 \mu \mathrm{M}$ (data not shown), the emulsion formed in culture media.

Defence against CEES remains limited (Table 3). MESNA and GSH were the only substances providing weak cytoprotection. MESNA is known to reduce the toxicity of alkylating agents during chemotherapy, including cyclofosfamide or ifosfamide (Matz and Hsieh, 2017). Its efficiency against CEES has not yet been documented. GSH, on the other hand, was demonstrated to decrease CEES-induced damage in vitro as well as in vivo (Han et al., 2004; McClintock et al., 2002; Sagar et al., 2014). According to our results, both compounds did not prevent initial DNA damage. It indicates that their scavenging of CEES and/or ROS generated during the first hour is not very effective and thus, not responsible for their cytoprotection. However, they reduced DNA alkylation in the $24 \mathrm{~h}$ interval, suggesting that both support DNA repair during 1-24 h interval. The mechanism of this action remains unknown. We may only assume that MESNA and GSH decrease the extent of ROS produced in the 1-24 period, creating a more permissive cellular environment to repair DNA adducts. The mixture of GSH and MESNA did not affect cell viability. Nonetheless, it represented 1 of 3 combinations decreasing \%tail DNA $1 \mathrm{~h}$ after CEES administration, which was even more pronounced at $24 \mathrm{~h}$. This effect may find its clinical use. Due to the relation of DNA damage response pathways to immune system activation, such mixtures might mitigate indirect inflammation-mediated tissue damage associated with CEES exposure (Jain et al., 2011; Nakad and Schumacher, 2016).

TU is a powerful scavenger of hydroxyl radicals (Wasil et al., 1987). We demonstrated TU to counteract SM-induced genotoxicity and cytotoxicity in our previous study (Jost et al., 2017). On this basis, we utilized the compound against CEES. According to our data, TU reduced the extent of DNA damage but it also negatively affected cell viability, implying TU not to be a universal antidote for blistering agents. Interestingly, its toxicity was further increased when combined with MESNA. Since we did not observe any potentiation of genoprotection it seems that TU and MESNA react with each other. Considering that the mixture was not found cytotoxic, toxic products are probably formed during reaction with CEES. Such a byproduct could be isothiouronium ion (Institute of Medicine /US/ Committee on the Survey of the Health Effects of Mustard Gas and Lewisite, 1993). This biologically active compound causes inhibition of protein kinase $C$ regulating metabolism, growth and cell death (Ferreira et al., 2017).

STS is utilized in patients receiving mechlorethamine (nitrogen mustard) chemotherapy in case of extravasal administration. STS neutralizes mechlorethamine to form nontoxic thioesters (Schulmeister, 2008). Balali-Mood and Hefazi (2006) also proposed STS as an antidote for SM poisoning. However, scavenging potential of STS towards CEES has not yet been tested. We found that STS most efficiently reduced CEES-induced DNA damage but, equivalently to TU, it had a negative impact on cell viability. Thus, even if STS produced a very high genoprotection, the result could be affected by the 
Table 3. Semi-quantitative summary of the chemoprotective efficacy of tested compounds and their combination with MESNA against CEES-induced damage

\begin{tabular}{|c|c|c|c|}
\hline Group & Protectant & Genoprotection & Cytoprotection \\
\hline \multirow{7}{*}{1} & MESNA & +++ & + \\
\hline & GSH & ++ & + \\
\hline & GSH + MESNA & +++ & 0 \\
\hline & TU & + & $\#$ \\
\hline & TU + MESNA & + & \# \\
\hline & STS & +++ & $\#$ \\
\hline & STS + MESNA & +++ & \# \\
\hline \multirow{6}{*}{2} & HMT & +++ & $\#$ \\
\hline & HMT + MESNA & +++ & $\#$ \\
\hline & 4-AAP & 0 & $\#$ \\
\hline & 4-AAP + MESNA & 0 & \# \\
\hline & HI-6 & + & \# \\
\hline & HI-6 + MESNA & ++ & $\#$ \\
\hline \multirow{6}{*}{3} & NAC & +++ & 0 \\
\hline & NAC + MESNA & +++ & 0 \\
\hline & MI & + & $\#$ \\
\hline & MI + MESNA & +++ & 0 \\
\hline & PYR & 0 & $\#$ \\
\hline & PYR + MESNA & ++ & $\#$ \\
\hline \multirow{4}{*}{4} & $3-\mathrm{AB}$ & + & 0 \\
\hline & 3-AB + MESNA & +++ & 0 \\
\hline & $\mathrm{NAm}$ & 0 & $\#$ \\
\hline & NAm + MESNA & ++ & \# \\
\hline \multirow{2}{*}{5} & L-NAME & 0 & $\#$ \\
\hline & L-NAME + MESNA & ++ & $\#$ \\
\hline
\end{tabular}

+++ strong protection, ++ moderate protection, + weak protection, 0 no protection, \# adverse toxic effect.

apoptotic or necrotic selection of damaged cells. Moreover, loss of cells during the early phase of poisoning may significantly aggravate tissue damage excluding STS from being a universal blistering agent antidote. The combination of STS and MESNA was 1 of 3 mixtures decreasing \%tail DNA $1 \mathrm{~h}$ after CEES exposure. But again, it reduced cell survival at $72 \mathrm{~h}$. Compared with STS used solely, MESNA mitigated the adverse effect of products resulting from STS and CEES interaction.

HMT, 4-AAP and HI-6 are available for human use. HMT is used in the treatment of urinary tract infection. It has been reported as an SM protectant in several studies (Andrew and Lindsay, 1998; Lindsay and Hambrook, 1997). 4-AAP is a selective cyclooxygenase-2 inhibitor indicated to alleviate fever and pain (Graham and Scott, 2005), whereas HI-6 is a bis-pyridinium oxime primarily developed as an antidote for nerve agents (Kuča et al., 2009). None of them appears to be a perspective countermeasure against CEES poisoning. In our in vitro model, HMT significantly potentiated CEES toxicity. MESNA reduced this outcome but this combination in itself did not bring any benefit compared to sole administration of MESNA. 4-AAP did not show any protective effects against CEES. In addition, it decreased genoprotection and cytoprotection provided by MESNA, which suggests that both compounds react with each other. From the clinical point of view, if MESNA is utilized as a CEES countermeasure, the timing of 4-AAP therapy to mitigate pain and itching would be essential in order to avoid undesirable drug interactions (Balali-Mood and Hefazi, 2006). Finally, HI-6 showed only weak genoprotection accompanied by loss of cell viability. It also negatively affected the activity of MESNA against CEES in the mixture. Thus, application of this combination against CEES or as a countermeasure to both nerve and blistering agents does not seem advisable.

In contrast to the previous group of tested compounds, NAC, a powerful antioxidant, appears very perspective. NAC is used to counteract acetaminophen and carbon monoxide poisoning (Flanagan and Meredith, 1991). It has been documented to reduce CEES toxicity (Paromov et al., 2008; Rappeneau et al., 2000), which is in accordance with our results. NAC most effectively decreased \%tail DNA at $24 \mathrm{~h}$ when administered solely and at $1 \mathrm{~h}$ when combined with MESNA. It is also noteworthy that there is no significant difference between NACMESNA and GSH-MESNA groups $24 \mathrm{~h}$ after CEES treatment. Additionally, if we subtract $1 \mathrm{~h}$ from $24 \mathrm{~h}$ data in NAC-MESNA group, the extent of DNA damage corresponds to what we measured in NAC-pretreated cells in the same interval. Both findings imply that mechanism(s) supporting repair of CEESDNA adducts during 1-24 h interval got saturated and further DNA protection might be possible only by active scavenging of CEES, reducing initial DNA damage.

MI and PYR are antioxidants. MI is a cyclic polyol and a component of phospholipid membranes. The molecule supports cell growth and survival (Croze and Soulage, 2013). PYR is commonly added to cell culture media as an additional source of energy. Kładna et al. (2015) observed the antioxidant activity of PYR derivatives possibly reflecting a direct effect on ROS scavenging. Both substances have not yet been tested against CEES. Nevertheless, the results show that they potentiated its cytotoxicity. In the case of MI, MESNA mitigated this consequence but it did not bring any benefit over sole administration of MESNA.

3-AB and NAm have been demonstrated to prevent alkylation of DNA and cytotoxicity induced by SM in human lymphocytes in vitro (Meier and Johnson, 1992). In our previous study, both molecules expressed genoprotection against SM in A-549 cells, having no effect on cell viability (Jost et al., 2017). Regarding CEES, two different outcomes were observed. 3-AB was the only substance reducing DNA damage, whereas NAm aggravated CEES cytotoxicity. The mechanism, by which 3-AB supports DNA repair, remains unknown. Since both 3-AB and NAm are PARP inhibitors, we may only hypothesize that it does not involve this enzyme. The combination of $3-A B$ with MESNA significantly improved the level of DNA damage induced by CEES but again, it did not reveal any advantage when compared with MESNA treated cells.

Finally, L-NAME represents the last tested compound. It is an arginine analogue with the potential to prevent SM toxicity in primary cultures of chick embryo forebrain neurons. However, these effects were not associated with its nitric oxide synthase-inhibiting characteristics (Sawyer, 1999). In our model, L-NAME did not show any protection against CEES.

\section{Conclusions}

In spite of CEES being considered less toxic than SM, it is still a powerful DNA alkylating agent. Our results show that it is difficult to prevent initial DNA damage induced by CEES using different compounds at maximal non-toxic concentrations in 
monotherapy. Significant chemoprotection was provided only by MESNA and GSH. NAC and 3-AB supported DNA repair but have no effect on cell viability. Other substances potentiated CEES-induced cytotoxicity and therefore, failed as perspective CEES countermeasures. The mixtures of GSH or NAC with MESNA significantly increased protection of DNA. This study demonstrates that a combination of different substances can provide protective synergy. However, adverse effects might occur as well. In vitro testing can reveal such outcomes and will help choose perspective mixtures. Their utilization could be a promising direction for future research in this field. Although in vitro screening cannot be fully transferred in vivo, it may help exclude compounds, which failed.

\section{Conflict of interest}

The authors declare that they have no conflict of interest.

\section{Acknowledgements}

The work was supported by the grant of The Ministry of Education, Youth and Sports of the Czech Republic No. SV/ FVZ20127 and long-term organization development plan Medical Aspects of Weapons of Mass Destruction of the Faculty of Military Health Sciences, University of Defense.

\section{References}

Abel EL, Bubel JD, Simper MS, Powell L, McClellan SA, Andreeff M, et al. (2011). Protection against 2-chloroethyl ethyl sulfide (CEES) - induced cytotoxicity in human keratinocytes by an inducer of the glutathione detoxification pathway. Toxicol Appl Pharmacol 255(2): 176-183. DOI: 10.1016/j.taap.2011.06.012.

Andrew DJ, Lindsay CD (1998). Protection of human upper respiratory tract cell lines against sulphur mustard toxicity by hexamethylenetetramine (HMT). Hum Exp Toxicol 17(7): 373-379. DOI: 10.1177/096032719801700703.

Balali-Mood M, Hefazi M (2006). Comparison of early and late toxic effects of sulfur mustard in Iranian veterans. Basic Clin Pharmacol Toxicol 99(4): 273-282. DOI: 10.1111/j.1742-7843.2006. pto_429.x.

Collins AR, Dusinská M, Horská A (2001). Detection of alkylation damage in human lymphocyte DNA with the comet assay. Acta Biochim Pol 48(3): 611-614.

Croze ML, Soulage CO (2013). Potential role and therapeutic interests of myo-inositol in metabolic diseases. Biochimie 95(10): 1811-1827. DOI: 10.1016/j.biochi.2013.05.011.

Debiak M, Lex K, Ponath V, Burckhardt-Boer W, Thiermann H, Steinritz D, et al. (2016). Immunochemical analysis of poly(ADPribosyl)ation in $\mathrm{HaCaT}$ keratinocytes induced by the monoalkylating agent 2-chloroethyl ethyl sulfide (CEES): Impact of experimental conditions. Toxicol Lett 244: 72-80. DOI: 10.1016/j. toxlet.2015.09.009

Ferreira M, Assunção LS, Silva AH, Filippin-Monteiro FB, CreczynskiPasa TB, Sá MM (2017). Allylic isothiouronium salts: The discovery of a novel class of thiourea analogues with antitumor activity. Eur J Med Chem 129: 151-158. DOI: 10.1016/j.ejmech.2017.02.013.

Flanagan RJ, Meredith TJ (1991). Use of $N$-acetylcysteine in clinical toxicology. Am J Med 91(3C): 131S-139S. DOI: 10.1016/00029343(91)90296-A.

Gould NS, White CW, Day BJ (2009). A role for mitochondrial oxidative stress in sulfur mustard analog 2-chloroethyl ethyl sulfide-induced lung cell injury and antioxidant protection. J Pharmacol Exp Ther 328(3): 732-739. DOI: 10.1124/ jpet.108.145037.

Graham GG, Scott KF (2005). Mechanism of action of paracetamol. Am J Ther 12(1): 46-55.

Guzyk MM, Tykhomyrov AA, Nedzvetsky VS, Prischepa IV, Grinenko TV, Yanitska LV, Kuchmerovska TM (2016). Poly(ADPRibose) polymerase-1 (PARP-1) inhibitors reduce reactive gliosis and improve angiostatin levels in retina of diabetic rats. Neurochem Res 41(10): 2526-2537. DOI: 10.1007/s11064-0161964-3.

Han S, Espinoza LA, Liao H, Boulares AH, Smulson ME (2004). Protection by antioxidants against toxicity and apoptosis induced by the sulphur mustard analog 2-chloroethylethyl sulphide (CEES) in Jurkat T cells and normal human lymphocytes. Br J Pharmacol 141(5): 795-802. DOI: 10.1038/sj.bjp.0705591.

Hara Y, McKeehan N, Dacks PA, Fillit HM (2017). Evaluation of the neuroprotective potential of $\mathrm{N}$-acetylcysteine for prevention and treatment of cognitive aging and dementia. J Prev Alzheimers Dis 4(3): 201-206. DOI: 10.14283/jpad.2017.22.

Institute of Medicine (US) Committee on the Survey of the Health Effects of Mustard Gas and Lewisite; Pechura CM, Rall DP (Eds.) (1993). Veterans at Risk: The Health Effects of Mustard Gas and Lewisite. Chemistry of Sulfur Mustard and Lewisite. Washington DC: National Academies Press (US). DOI: 10.17226/2058.

Inturi S, Tewari-Singh N, Gu M, Shrotriya S, Gomez J, Agarwal C, et al. (2011). Mechanisms of sulfur mustard analog 2-chloroethyl ethyl sulfide-induced DNA damage in skin epidermal cells and fibroblasts. Free Radic Biol Med 51(12): 2272-2280. DOI: 10.1016/j.freeradbiomed.2011.08.020.

Jain AK, Tewari-Singh N, Gu M, Inturi S, White CW, Agarwal R (2011). Sulfur mustard analog, 2-chloroethyl ethyl sulfide-induced skin injury involves DNA damage and induction of inflammatory mediators, in part via oxidative stress, in SKH-1 hairless mouse skin. Toxicol Lett 205(3): 293-301. DOI: 10.1016/j. toxlet.2011.06.019.

Jost P, Fikrova P, Svobodova H, Pejchal J, Stetina R (2017). Protective potential of different compounds and their combinations with MESNA against sulfur mustard-induced cytotoxicity and genotoxicity. Toxicol Lett 275: 92-100. DOI: 10.1016/j. toxlet.2017.05.010.

Jost P, Svobodova H, Stetina R (2015). Induction and repair of DNA cross-links induced by sulfur mustard in the A-549 cell line followed by a comet assay. Chem Biol Interact 237: 31-37. DOI: 10.1016/j.cbi.2015.05.009.

Kehe K, Raithel K, Kreppel H, Jochum M, Worek F, Thiermann H (2008). Inhibition of poly(ADP-ribose) polymerase (PARP) influences the mode of sulfur mustard (SM)-induced cell death in HaCaT cells. Arch Toxicol 82(7): 461-470. DOI: 10.1007/s00204007-0265-7.

Kehe K, Schrettl V, Thiermann H, Steinritz D (2013). Modified immunoslotblot assay to detect hemi and sulfur mustard DNA adducts. Chem Biol Interact 206(3): 523-528. DOI: 10.1016/j. cbi.2013.08.001.

Kładna A, Marchlewicz M, Piechowska T, Kruk I, Aboul-Enein HY (2015). Reactivity of pyruvic acid and its derivatives towards reactive oxygen species. Lumin. J Biol Chem Lumin 30(7): 1153-1158. DOI: 10.1002/bio.2879.

Kuča K, Musílek K, Jun D, Pohanka M, Karasová JZ, Novotný L, Musilová L (2009). Could oxime HI-6 really be considered as "broad-spectrum" antidote? J Appl Biomed 7(3): 143-149. DOI: 10.32725/jab.2009.016.

Lindsay CD, Hambrook JL (1997). Protection of A549 cells against the toxic effects of sulphur mustard by hexamethylenetetramine. Hum Exp Toxicol 16(2): 106-114. DOI: $10.1177 / 096032719701600206$.

Maher P (2017). Potentiation of glutathione loss and nerve cell death by the transition metals iron and copper: Implications for age-related neurodegenerative diseases. Free Radic Biol Med 115: 92-104. DOI: 10.1016/j.freeradbiomed.2017.11.015.

Matz EL, Hsieh MH (2017). Review of advances in uroprotective agents for cyclophosphamide- and ifosfamide-induced hemorrhagic cystitis. Urology 100: 16-19. DOI: 10.1016/j. urology.2016.07.030.

McClintock SD, Till GO, Smith MG, Ward PA (2002). Protection from half-mustard-gas-induced acute lung injury in the rat. J Appl Toxicol 22(4): 257-262. DOI: 10.1002/jat.856.

Meier HL, Johnson JB (1992). The determination and prevention of cytotoxic effects induced in human lymphocytes by the alkylating agent 2,2'-dichlorodiethyl sulfide (sulfur 
mustard, HD). Toxicol Appl Pharmacol 113(2): 234-239. DOI: 10.1016/0041-008X(92)90119-D.

Mosmann T (1983). Rapid colorimetric assay for cellular growth and survival: Application to proliferation and cytotoxicity assays. J Immunol Methods 65(1-2): 55-63. DOI: 10.1016/00221759(83)90303-4.

Nakad R, Schumacher B (2016). DNA damage response and immune defense: links and mechanisms. Front Genet 7: 147. DOI: 10.3389/fgene.2016.00147.

Palmieri M, Papale P, Della Ragione A, Quaranta G, Russo, G, Russo S (2016). In Vitro Antioxidant treatment of semen samples in assisted reproductive technology: effects of myo-inositol on nemaspermic parameters. Int J Endocrinol 2016: ID 2839041. DOI: $10.1155 / 2016 / 2839041$.

Paromov V, Qui M, Yang H, Smith M, Stone WL (2008). The influence of $N$-acetyl-L-cysteine on oxidative stress and nitric oxide synthesis in stimulated macrophages treated with a mustard gas analogue. BMC Cell Biol 9: 33. DOI: 10.1186/1471-2121-9-33.

Rappeneau S, Baeza-Squiban A, Marano F, Calvet J (2000). Efficient protection of human bronchial epithelial cells against sulfur and nitrogen mustard cytotoxicity using drug combinations. Toxicol Sci 58(1): 153-160. DOI: 10.1093/toxsci/58.1.153.

Ravindran S, Boovarahan SR, Shanmugam K, Vedarathinam RC, Kurian GA (2017). Sodium thiosulfate preconditioning ameliorates ischemia/reperfusion injury in rat hearts via reduction of oxidative stress and apoptosis. Cardiovasc Drugs Ther 31(5-6): 511-524. DOI: 10.1007/s10557-017-6751-0.

Sagar S, Kumar P, Behera RR, Pal A (2014). Effects of CEES and LPS synergistically stimulate oxidative stress inactivates OGG1 signaling in macrophage cells. J Hazard Mater 278: 236-249. DOI: 10.1016/j.jhazmat.2014.05.096.

Sagar S, Parida SR, Sabnam S, Rizwan H, Pal S, Swain MM, Pal A (2017). Increasing NO level regulates apoptosis and inflammation in macrophages after 2-chloroethyl ethyl sulphide challenge. Int J Biochem Cell Biol 83: 1-14. DOI: 10.1016/j.biocel.2016.12.004.
Sawyer TW (1999). Synergistic protective effects of selected arginine analogues against sulphur mustard toxicity in neuron culture. Toxicol Appl Pharmacol 155(2): 169-176. DOI: 10.1006/ taap.1998.8588.

Sawyer TW, McNeely K, Louis K, Lecavalier P, Song Y, Villanueva M, Clewley R (2017). Comparative toxicity of mono- and bifunctional alkylating homologues of sulphur mustard in human skin keratinocytes. Toxicology 382: 36-46. DOI: 10.1016/j. tox.2017.03.005.

Schulmeister L (2008). Managing vesicant extravasations. Oncologist 13(3): 284-288. DOI: 10.1634/theoncologist.2007-0191.

Srivastava AK, Srivastava S, Penna S, D’Souza SF (2011). Thiourea orchestrates regulation of redox state and antioxidant responses to reduce the $\mathrm{NaCl}$-induced oxidative damage in Indian mustard [Brassica juncea (L.) Czern.]. Plant Physiol Biochem 49(6): 676-686. DOI: 10.1016/j.plaphy.2011.02.016.

Tewari-Singh N, Inturi S, Jain AK, Agarwal C, Orlicky DJ, White CW, et al. (2014). Catalytic antioxidant AEOL 10150 treatment ameliorates sulfur mustard analog 2-chloroethyl ethyl sulfide associated cutaneous toxic effects. Free Radic Biol Med 72: 285-295. DOI: 10.1016/j.freeradbiomed.2014.04.022.

Wasil M, Halliwell B, Grootveld M, Moorhouse CP, Hutchison DC, Baum H (1987). The specificity of thiourea, dimethylthiourea and dimethyl sulphoxide as scavengers of hydroxyl radicals. Their protection of alpha 1-antiproteinase against inactivation by hypochlorous acid. Biochem J 243(3): 867-870. DOI: 10.1042/ bj2430867.

Yiannakopoulou E, Nikiteas N, Perrea D, Tsigris C (2012). Pharmacological modulation of oxidative stress response in minimally invasive surgery: systematic review. Surg Laparosc Endosc Percutan Tech 22(3): 200-204. DOI: 10.1097/ SLE.0b013e318247d15e. 